site with respect to that of another, and therefore the rates estimated from tide gauge data are unaffected by any secular sea level change common to all sites. The comparison is a good check on our results since it is independent of both the Earth model and the load history.

Although the uncertainties associated with the GPS determinations of vertical rates are currently larger than those associated with the tide gauge rates, they will decrease rapidly over the next few years. Soon, GPS rates will provide as much or more geophysical information than the tide gauge rates because of the greater geographic coverage of the GPS network. Also, GPS provides "absolute" uplift, that is, uplift relative to a satellitebased terrestrial reference frame rather than to the sea level. Over the next few years, efforts to identify and eliminate, or at least quantify, effects associated with signal propagation and scattering, site instability, and orbit and reference frame errors will continue.

Acknowledgments: This work was supported in part by NASA (grant NAG5-538), the Natural Science and Research Council of Sweden, the Smithsonian Institution, the Knut and Alice Wallenberg Foundation, the Natural Sciences and Engineering Research
Council of Canada, and the Institute for International Programs at the University of Toronto. The organizations participating in BIFROST are: the Harvard-Smithsonian Center for Astrophysics, the Onsala Space Observatory, the National Land Survey of Sweden, the University of Toronto, and the Finnish Geodetic Institute.

BIFROST Project Members: $R$. A. Bennett,

T. R. Carlsson, T. M. Carlsson, R. Chen,

J. L. Davis, M. Ekman, G. Elgered, P. Elósegui,

G. Hedling, R. T. K. Jaldehag, P. O. J. Jarle-

mark, J. M. Johansson, B. Jonsson, J. Kakkuri,

H. Koivula, G. A. Milne, J. X. Mitrovica,

B. I. Nilsson, M. Olikainen, M. Paunonen,

M. Poutanen, R. N. Pysklywec, B. O. Rön-

näng, H.-G. Scherneck, I. I. Shapiro, and M.

Vermeer

\section{References}

Davis, J. L., and J. X. Mitrovica, Glacial isostatic adjustment and the anomalous tide gauge record of eastern North America, $\mathrm{Na}$ ture, 379, 331, 1996

Elósegui, P., J. L. Davis, R. K. Jaldehag, J. $M$. Johansson, A. E. Niell, and I. I. Shapiro, Geodesy using the Global Positioning System: The effects of signal scattering on estimates of site position, J. Geophys. Res., 100, 9921, 1995
Jaldehag, R. T. K., J. M. Johansson, J. L Davis, and P. Elósegui, Geodesy using the Swedish permanent GPS network: Effects of snow accumulation on estimates of site position, Geophys. Res. Lett., 23, 1601, 1996.

James, T. S., and A Lambert, A comparison of VLBI data with the JCE-3G glacial rebound model, Geophys. Res. Lett., 20, 871, 1993.

Mitrovica, J. X., Haskell [1935] revisited, $J$ Geophys. Res., 101, 555, 1996.

Mitrovica, J. X., J. L. Davis, and I. I Shapiro, Constraining proposed combinations of ice history and Earth rheology using VLBI determined baseline length rates in North America, Geophys. Res. Lett., 20, 2387, 1993.

Mitrovica, J. X., J. L. Davis, and I. I Shapiro, A spectral formalism for computing three-dimensional deformations due to surface loads, 1, Theory, J. Geophys. Res., $99,7057,1994 a$

Mitrovica, J. X., J. L. Davis, and I. I

Shapiro, A spectral formalism for computing three-dimensional deformations due to surface loads, 2, Present-day glacial isostatic adjustment, J. Geophys. Res., 99, 7075, 1994b.

Nakada, M., and K. Lambeck, Late Pleistocene and Holocene sea level change in the Australian region and mantle rheology, J. Geophys. Res., 96, 497, 1989.

Tushingham, A. M., and W. R. Peltier, ICE 3G: A new global model of late Pleistocene deglaciation based upon geophysical predictions of postglacial relative sea level change, J. Geophys. Res., 96, 4497, 1991.

\title{
Development of Recurrent Coastal Plume in Lake Michigan Observed for First Time
}

\section{PAGES 337-338}

NOAA CoastWatch satellite imagery from early 1996 captured the initiation, development, and decay of a recurrent coastal plume in southern Lake Michigan (Figure 1). For the past 4 years intermittent satellite coverage has revealed a late winter-early spring plume in the lake, a feature also observed by Mortimer [1988]. In 1996, clear weather conditions allowed researchers to observe the plume's development for the first time and they also collected water samples from helicopter and a small boat.

Preliminary results imply that the reflective substances in the plume comprise a substantial fraction of the total particle load to the lake and are similar to silty-clay materials eroding from bluffs along the shore of Lake Michigan or from exposed glacial clay deposits in shallow waters. Since these fine-grained materials are excellent substrates for sorption, this episodic event will play an important role in scavenging particles of contaminants such as PCBs from the lake waters to be absorbed by the sediments. The plume also plays a substantial role in phosphorus (P) cycling, thus it is important in the development of the spring diatom bloom and subsequent production. Finally, the offshore eddies in the southeastern portion of the plume coincide with the area of maximum sediment accumulation in the lake, which implies that this event plays an important role in depositional patterns and subsequent sediment-water interactions.

The onset of the plume coincided with the disappearance of ice in the southern basin in late March, and with the occurrence of a major storm with strong northerly winds. Northerly winds can generate large waves in the southern part of the lake and currents that tend to run southward along the east and west coasts of the southern basin. These currents typically converge to produce offshore flow somewhere along the southeast shore; the exact location depends on the strength, direction, and duration of the wind. Within a few days, the plume was approximately 10 $\mathrm{km}$ wide and over $100 \mathrm{~km}$ long, implying that the source of the reflective materials is widely distributed alongshore. The feature persisted for over a month. Wind direction was predominantly from the north during this period. The few clear satellite images of the plume from previous years suggest that this year's plume may have persisted longer than usual.

Water temperature estimated from the thermal band in the satellite imagery was nearly uniform at about $1^{\circ} \mathrm{C}$ throughout the southern basin. Conductivity-temperature- depth (CTD) profiles to depths of up to $60 \mathrm{~m}$ in the plume revealed constant temperature and transparency. Only at one station, located visually at the edge of the plume, did transparency decrease significantly with depth which implies that some of the sediment settled and was transported offshore. Total suspended matter (TSM) ranged from 4-10 $\mathrm{mg} / \mathrm{L}$ at 4 plume stations, compared with an average of $1 \cdot \mathrm{mg} / \mathrm{L}$ measured at background stations. A correlation of surface TSM and channel 1 reflectance was used to estimate the TSM over the entire plume area as recorded in the April 1 satellite image. We conservatively calculate $3 \times 10^{5}$ tons of TSM, $25 \%$ of the estimated annual load of 'mud' to the southern basin [Colman and Foster, 1994].

$P$ is the least abundant nutrient in the Great Lakes, which generally limits the primary productivity of biota. High concentrations of particulate and available $P$ measured within the plume imply either an unidentified external source of considerable significance or undescribed internal nutrient dynamics. Chlorophyll ranged between 1.4 and $1.8 \mu \mathrm{g} / \mathrm{L}$ for all samples, with levels within the plume $12-14 \%$ below open lake concentrations. Biomass of diatoms that dominated the phytoplankton at this time was greatest in the plume. A small $(\sim 7 \mu \mathrm{m})$ centric diatom accounted for over $50 \%$ at all stations, however significantly higher numbers of Stephanodiscus parvus, usually associated with elevated nutrient conditions, 


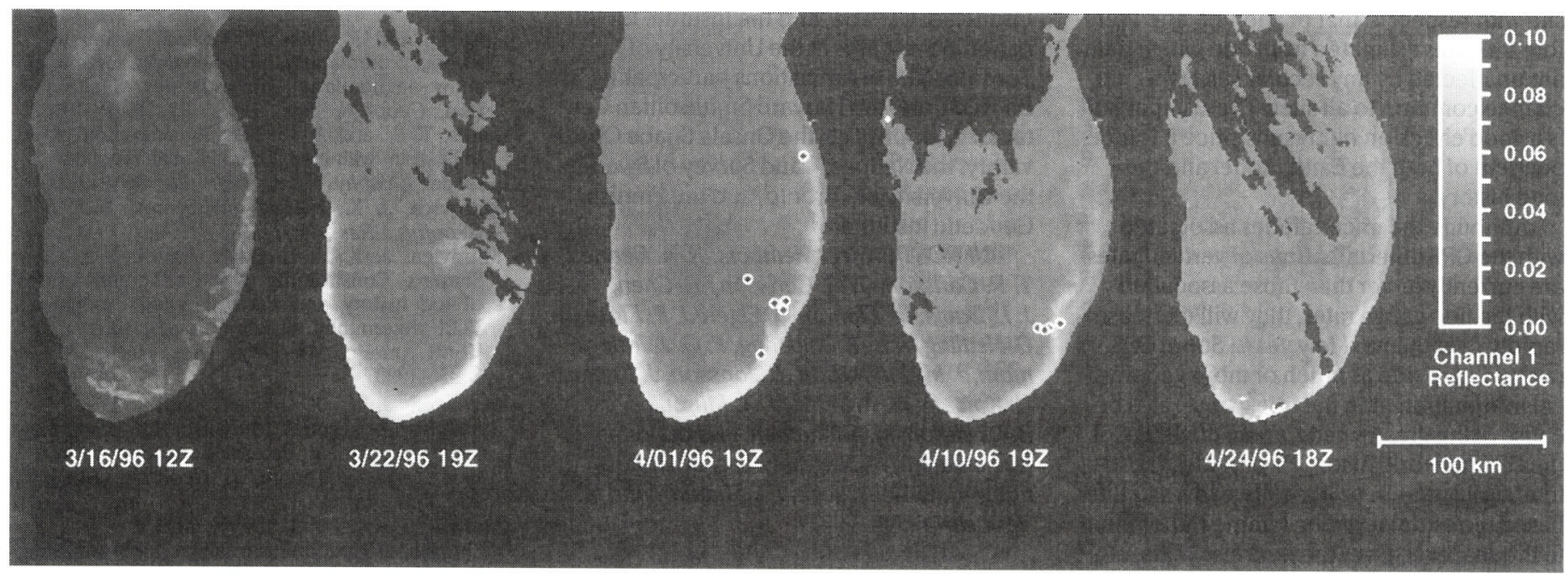

Fig. 1. Visible band satellite imagery of southern Lake Michigan. On March 16, the NOAA 12 (morning) AVHRR Channel 1 satellite image shows shore-fast ice along the eastern shore of the southern basin and large ice floes at the south end of the lake. After several days of warming temperatures and strong northerly winds, the March 22 NOAA 14 (afternoon) image shows the presence of a highly reflective plume that appears to originate along the southwestern shoreline and extend eastward along the southern shore. On April 1, a helicopter was used to collect five samples from the plume region and one sample and two conductivity-temperature-depth profiles were collected from ship further north. A subsequent set of four samples and conductivity-temperature-depth profiles were collected by small boat on April 10. Sampling locations are marked by crosses. By April 24, the plume extended along the entire eastern shore, but the intensity was considerably diminished. The majority of the western shoreline is composed of silty-clay bluffs [Jibson et al., 1994], while the southern shore is highly industrialized with extensive man-made features. The eastern shore is primarily sandy beaches backed by dunes. The pattern of sediment accumulation is highly asymmetric; the western and southern regions do not accumulate recent sediments, while the highest sediment accumulation in the lake is on the southeastern slope (coincident with the eddy features in the figure) and not in the deep central region. Clouds are masked out on the March 22, April 10, and April 24 images.

were observed within the plume. The microbial community (picocyanobacteria, bacteria, and protozoa) was highest at the edge of the plume. These results suggest that the plume region is promoting biological activity.

Several potential tracers were analyzed to identify the source of the TSM in the plume. The low organic carbon and high $\mathrm{C} / \mathrm{N}$ ratios compared to the open lake values were similar to a bluff sample from the western side of the lake. The $\delta^{15} \mathrm{~N}$ of the organic matter in the plume also resembled bluff material as well as samples measured deep in lake cores; more recent, anthropogenically impacted core materials are significantly different. TSM in the plume had a lower activity of ${ }^{137} \mathrm{Cs}$ than background TSM or recent fine-grained sediments that still contain the signature of this fallout radionuclide from the early 1960s.

These preliminary compositional results are consistent with silty-clay materials eroding from bluffs along the shore of Lake Michigan or from exposed glacio-lacustrine clays in shallow waters. The initiation of this event may signal the breakup of the nearshore ice complex as a result of the March 20 storm and resuspension of materials temporarily stored in the coastal region. In addition to the plumes' impact on the cycling and transport of nutrients, it may also provide material to the benthic nepheloid layer that plays a major role in the coupling of the constituents in surface sediments with overlying lake water throughout the year.

The timing of the event relative to lake warming and increased solar irradiance will be important in the development of the spring diatom bloom and subsequent production. Biological recycling of nutrients within the upper layer of the water column is very efficient. The nutrients present in this layer when the lake thermally stratifies is the fuel that determines the magnitude of annual productivity.-B. J. Eadie, D. J. Schwab,

R. A. Assel, N. Hawley, M. B. Lansing,

G. S. Miller, N. R. Morehead, J. A. Robbins, and P. L. Van Hoof, NOAA Great Lakes Environmental Research Laboratory, Ann Arbor, Mich.; G. A. Leshkevich, NOAA Great Lakes Environmental Research Laboratory, Ann Arbor, Mich., and Air Station Traverse City, U.S. Coast Guard Ninth District, Traverse City, Mich.; T. H. Johengen and P. Lavrentyeu, Cooperative Institute for Limnology and Ecosystem Research, Ann Arbor, Mich.; and R. E. Holland, University of Michigan, Atmospheric, Oceanic and Space Sciences, Ann Arbor, Mich.

\section{References}

Colman, S. M., and D. S. Foster, A sediment budget for southern Lake Michigan: Source and sink models for different time intervals, J. Great Lakes Res., 20, 215, 1994.

Jibson, R.W., J. K. Odum, and J. Staude, Rates and processes of bluff erosion along the Lake Michigan shoreline in lllinois, $J$. Great Lakes Res., 20, 135, 1994.

Mortimer, C. H., Discoveries and testable hypotheses arising from Coastall Zone Color Scanner imagery of southern Lake Michigan, Limnol. Oceanogr., 33, 203, 1988.

\section{Public Knows the Value of Science, But Not the Meaning}

\section{PAGE 339}

The first of two parts in a series.

Americans love science, they just don't necessarily understand it. That is the mes- sage of Science \& Engineering Indicators 1996, a compendium of statistics on science funding, education, and public attitudes toward science. The report was researched and drafted under the guidance of the Na- tional Science Board of the National Science Foundation (NSF).

In a survey of 2,006 Americans, $72 \%$ of those questioned agreed that the benefits of scientific research outweigh any harmful results; that percentage has been consistent since NSF first started compiling the Indicators in 1979 (Figure 1). Public interest in the fruits of science research also is high, according to the survey. At least $44 \%$ of respondents considered themselves "very interested" in scientific discoveries and another $45 \%$ con- 